\title{
PERBUDAKAN DI BENUA AMERIKA SEBELUM DAN SESUDAH PELAYARAN COLOMBUS
}

\author{
Anwar Firdaus Mutawally ${ }^{1}$ \\ ${ }^{1}$ Universitas Pendidikan Indonesia \\ Anwarfirdausmutawally@gmail.com
}

\section{Perbudakan di benua Amerika sebelum pelayaran Colombus}

Perbudakan telah lama dilakukan oleh penduduk asli benua Amerika jauh sebelum kedatangan Christopher Colombus ke benua Amerika. Umumnya budak diperoleh dari tawanan perang atau seseorang yang gagal melunasi hutangnya. Pada peradaban Aztec dan Maya, para buruh biasanya dipekerjakan sebagai pembangun kuil dan sebagian lainnya dijadikan sesembahan bagi para dewa (Revue, 2002, hlm. 175).

Pada kerajaan Inca, dikenal sistem mit'a yakni mengirim salah satu anggota keluarga untuk membayar pajak kepada pemerintah dengan menjadi seorang budak. Anggota keluarga yang menjadi budak ini kemudian dipekerjakan untuk pembangunan infrastruktur seperti jalan, jembatan, maupun irigasi (de Diez Canseco, 1999, hlm. 61). Suku-suku Indian seperti Carib, Comanche, dan Tupinamba juga mengenal sistem perbudakan. Meskipun demikian, perbudakan yang dilakukan penduduk asli Amerika tidak bersifat turun temurun. Sehingga keturunan dari budak ini berstatus merdeka dan memiliki hak bebas layaknya penduduk lainnya.

\section{Perbudakan di benua Amerika setelah pelayaran Colombus}

Setelah pelayaran Colombus ke belahan barat bumi pada tahun 1492, bangsa Eropa membawa tradisi baru ke benua Amerika, yakni perdagangan budak antar samudra. Perdagangan budak ini dikenal pula dengan istilah Trans Atlantic Slave Trade (Perdagangan budak trans-Atlantik). Perdagangan budak mulai dilakukan pada tahun 1441 saat Antão Gonçalves membeli sepuluh budak dari Afrika untuk dibawa ke Portugal (Williams, 2014, hlm. 24-25). Meskipun demikian, dampak perdagangan budak trans-Atlantik baru terasa di benua Amerika sejak tahun 1518, dimana Spanyol mengesahkan Asiento de Negros, yakni sebuah monopoli perdagangan budak Afrika.

Sebelum mempekerjakan budak asal Afrika, bangsa Eropa di benua Amerika menggunakan bangsa Indian sebagai budak di perkebunan maupun pertambangan. Contoh pertama perbudakan bangsa Indian oleh bangsa Eropa ialah pertambangan emas di Cibao pada tahun 1494. Selain itu, pada tahun 1495, Christopher Colombus menjual 550 orang Indian ke Spanyol (Reséndez, 2016, hlm. 27). Namun perbudakan 
terhadap bangsa asli Amerika berdampak buruk, sebab bangsa Indian tidak memiliki imunitas terhadap penyakit yang dibawa dari benua Eurasia maupun Afrika seperti cacar, campak, maupun Influenza. Selain itu, pemerintah Spanyol juga melarang perbudakan terhadap penduduk asli Amerika sejak tahun 1499 (Reséndez, 2016, hlm. 18-19).

Untuk mengatasi permasalahan ini, pada tahun 1518, kerajaan Spanyol mengesahkan Asiento de Negros, yakni monopoli perdagangan budak kulit hitam ke benua Amerika oleh pedagang katolik. Monopoli ini memulai perdagangan budak ke benua Amerika. Perdagangan budak Trans Atlantik kemudian terbagi menjadi dua fase, yakni fase pertama yang dikuasai oleh Portugis dan Spanyol, serta fase kedua yang dikuasai oleh Inggris, Prancis, dan Belanda.

Fase Pertama perdagangan budak Trans Atlantik terjadi antara tahun 1525 hingga akhir abad ke-17, pada fase ini para budak dibawa untuk dipekerjakan sebagai budak di wilayah kolonial Spanyol dan Portugal di benua Amerika seperti Brazil, Meksiko, maupun Kuba. Spanyol dan Portugis mendapatkan keuntungan terbesar dari perdagangan budak pada masa bersatunya Iberia (1580-1640). Meskipun demikian, monopoli Spanyol dan Portugis terhadap perdagangan budak mengalami keruntuhannya pada masa Perang Penerus Spanyol (1701-1714). Asiento de Negros kemudian diserahkan kepada Inggris dengan ditandatangani perjanjian Utrecht pada tahun 1713 (Christopher, 2006, hlm. 6).

Fase kedua terjadi pada pertengahan abad ke-17 hingga dihapuskannya perbudakan pada abad ke-19, pada fase ini perdagangan budak dikuasai oleh Inggris, Prancis dan Belanda dan mencakup lebih dari separuh jumlah total budak yang diperjualbelikan dalam perdagangan Trans Atlantik. Para budak pada fase ini umumnya dibawa ke Kepulauan Karibia dan Amerika Utara (Meredith, 2014, hlm. 191-193).

Pada tahun 1621, Anthony Johnson, orang kulit hitam pertama tiba di koloni Virginia sebagai pekerja kontrak. Meskipun demikian, pada tahun 1641, koloni Massachusett mengesahkan kebijakan diperbolehkannya perbudakan dengan syarat budak tersebut diperoleh dari warga non-inggris maupun tawanan perang. Akibat kebutuhan yang besar untuk mengurusi perkebunan di Amerika Utara, pemerintah Inggris kemudian mengesahkan kebijakan Partus sequitur ventrem pada tahun 1662 dengan ujicoba di koloni Virginia, sejak saat itulah orang-orang kulit hitam dirampas hak hidupnya oleh bangsa Eropa (Wood, 1970, hlm. 49). Kapal terakhir yang mengangkut budak kulit hitam di Amerika Serikat ialah Clotilda pada tahun 1859 yang berlabuh di Alabama, Amerika Serikat, dua tahun sebelum terjadinya perang saudara.

Perbudakan yang dilakukan oleh bangsa Eropa umumnya bersifat turun temurun atau dikenal pula dengan istilah Partus sequitur ventrem. Selain sifat turun 
temurun, majikan para budak juga tak jarang bersikap kasar dan menyiksa budak yang membangkang. Para budak kulit hitam yang tak tahan dengan perlakuan majikannya lalu melarikan diri ke pedalaman hutan dan dikenal dengan istilah Maroons. Para Maroons ini seringkali melakukan perkawinan dengan bangsa Indian, dari perkawinan ini menghasilkan suku kreol seperti Garifuna di Belize maupun Saramacca di Suriname (Manzo, 1998. 417).

\section{Akhir Perbudakan di Benua Amerika}

Disahkannya Deklarasi Hak Asasi Manusia dan Warga Negara di Prancis pada 26 Agustus 1789 berdampak besar terhadap akhir perbudakan. Deklarasi ini menginspirasi Toussaint L'Ouverture untuk melancarkan revolusi Haiti pada tahun 1791. Perjuangan budak hitam di Haiti terbukti berhasil dan Haiti merdeka dari Prancis pada tahun 1804 (Dubois, 2005, hlm. 91). Kemerdekaan Haiti membuka mata hati bangsa Eropa terhadap buruknya sistem perbudakan. Begitu pun dengan Inggris yang meninggalkan perbudakan pada tahun 1833 dengan disahkannya Slavery Abolition Act.

Selama awal abad ke-19, perbudakan masih dilakukan di daerah seperti Brasil, Kuba, Amerika Serikat. Penghapusan perbudakan baru dimulai di benua Amerika pada masa perang kemerdekaan Amerika Spanyol (1810-1826), secara bertahap negara-negara di benua Amerika mulai meninggalkan sistem perbudakan. Negara pertama di benua Amerika yang menghapus perbudakan ialah Chili pada tahun 1811 dan Brasil menjadi negara terakhir yang menghentikan perbudakan pada tahun 1888 (Hinks dan McKivigan, 2015, hlm. 430).

Penghapusan perbudakan tidak selalu diterima secara baik, kebijakan ini menjadi penyebab utama terjadinya perang saudara Amerika Serikat (1861-1865). Pihak Konfederasi menolak penghapusan sistem perbudakan sehingga memisahkan diri dari Amerika Serikat pada Februari 1861, tujuh negara bagian di Selatan Amerika Serikat memisahkan diri untuk membentuk negara Konfederasi. Perbudakan di Amerika Serikat secara resmi berhenti dengan berakhirnya perang saudara dan disahkannya Amandemen ke-13 pada 6 Desember 1865 (Williams, 2014, hlm. 107-109). 


\section{DAFTAR PUSTAKA}

Christopher, E. (2006). Slave ship sailors and their captive cargoes, 1730-1807. Cambridge: Cambridge University Press.

de Diez Canseco, M. R. (1999). History of the Inca realm. Cambridge: Cambridge University Press.

Dubois, L. (2005). Avengers of the new world. Cambridge: Harvard University Press.

Hinks, P., \& McKivigan, J. (2015). Abolition and antislavery: A historical encyclopedia of the American mosaic. Santa Barbara: ABC-CLIO.

Manzo, T. (1998). Columbus Then and Now: A Life Re-examined. Oklahoma: University of Oklahoma Press

Meredith, M. (2014). The Fortunes of Africa: A 5000-Year History of Wealth, Greed, and Endeavor. New York: PublicAffairs.

Reséndez, A. (2016). The Other Slavery: The Uncovered Story of Indian Enslavement In America. Boston: Houghton Mifflin Harcourt.

Testart, A. (2002). The extent and significance of debt slavery. Revue française de sociologie, 173-204.

Williams, H. A. (2014). American slavery: A very short introduction. Oxford: Oxford University Press.

Wood, W. J. (1970). The Illegal Beginning of American Negro Slavery. American Bar Association Journal, 45-49, 56 (1). 